\title{
The Failed Attempt to Relaunch the WEU and the Issue of the First Enlargement
}

\author{
Vincent DUJARDIN
}

On 27 November 1967, Charles de Gaulle dealt the death blow to the British candidacy. ${ }^{1}$ The Council of EEC Foreign affairs ministers of 18 and 19 December 1967 had to conclude without agreement on this question. France made it known at the meeting that unlike the Commission, which had given its support to enlargement on 29 September, France felt that the British economy would need to recover fully before the British request could be reconsidered.

Following the second French veto, Belgian diplomats wished to take the initiative in order to give new momentum to European integration. They felt that a solution should be found outside the particular context of the Treaty of Rome, promoting a bold type of European policy looking towards a technological, political and defence community. An initial specific proposal was put to the Six in the guise of a memorandum from the Benelux countries in January 1968.

A second initiative came from Belgium alone and ended in a stalemate. From February 1969 until April 1970, France operated an empty chair policy at ministerial meetings of the Western European Union. At the time, this institution was in the throes of a real crisis. This had arisen following the proposal from the Belgian Foreign Office, in October 1968, to develop consultations within the WEU on economic and monetary matters, technology, but also foreign policy and defence. While France under general de Gaulle rejected the proposal out of hand, the United Kingdom called a meeting of the WEU Standing Committee in London on 14 February, and upheld the invitation even when France refused to participate. The ensuing crisis was directly linked to the issue of British accession to the EEC, demonstrated the tensions between larger and smaller countries, and requires being put into context.

In the historical writings concerning the history of European integration, little has been written about the crisis within the WEU. However, judging from the volume of material in the archives of the Foreign affairs ministries of the two countries most closely concerned (France and Great Britain), it had been a matter of great concern to the chancelleries, for several months. There is an impressive amount of chancellery material on the WEU crisis, which shows that the Harmel plan may have provoked as much of a reaction in these two countries as the Harmel exercise on the future tasks of the Atlantic Alliance. This could be because the question of British accession to the EEC was a constant backdrop to these discussions.

1. Cf. M.-T. BITSCH, Histoire de la construction européenne, Complexe, Bruxelles, 2004, p. 168. 


\section{The Benelux memorandum: an initial reaction to the second French veto}

The Benelux memorandum of 15 January 1968 was the result of a Belgian initiative. On 26 September 1966, during a visit to the Hague accompanying Prime minister Paul Vanden Boeynants, Pierre Harmel already raised the idea of technological cooperation between the Benelux countries, in order to strengthen the Benelux while still being ready to work with Great Britain in this area. ${ }^{2}$ At that time, Harmel had been Foreign affairs minister of Belgium since March 1966. He would remain in this post until January 1973. He had already been minister of Education from 1950 until 1954, then Prime minister from 1965 to 1966.

Moreover, in February 1967, Harmel, together with the German chancellor, had considered the same type of project, which was also being studied in Great Britain. On 30 November 1967 a Foreign Office official, Sir Con O'Neill, responsible in particular for accession and at the head of the British delegation during negotiations on British accession to the EEC, suggested to the Dutch secretary of State, Hans J. De Koster, with a view to the Council of ministers of the Six on 18 and 19 December 1967, that the Five should work together with Great Britain in the areas of technology, inventors' patents and company law for limited companies. ${ }^{3}$

France's negative attitude at the Council of ministers meeting on 18-19 December led the Netherlands and Belgium to take the idea further and to prepare their own document. The two texts, however, take quite different approaches. ${ }^{4}$ The Belgian text stresses the idea of cooperation within the community and the role of the Commission, while the Dutch document proposes straightaway cooperation between Great Britain, the Five and other candidate countries, outside the European institutional context.

The three Benelux ministers for Foreign affairs met again on 15 January 1968 to agree on a common text. Belgium and Luxembourg were concerned not to provoke conflict with France, while the Netherlands wished to make a strong gesture in order to show the British that they could count on their faithful continental friends. Harmel felt that the Five countries could organise political discussions with Great Britain without prior agreement from France, since the issues at stake were procedural, not questions of substance, and could therefore be decided by a qualified majority. He suggested the WEU as a suitable setting for these consultations between Great Britain and the Five: an idea rejected by Luxembourg and the Netherlands. ${ }^{5}$

The final document was submitted by Belgium and the Netherlands, following the meeting of Benelux ministers on 15 January, although Luxembourg seemed less

2. Record of the visit in the Archives of the Ministry of Foreign Affairs of the Netherlands (AMFANL), 2016.

3. As reported by De Koster to the Dutch Council of ministers on 1 December 1967. General Archives of the Netherlands (GANL).

4. They can be found in the National Archives of Luxembourg, Archives of the Ministry of Foreign Affairs of Luxembourg (NAL, AMFAL), 15452.

5. Ibid., Record of the meeting. 
than enthusiastic. They had felt for several days that the Belgian position was "unrealistic", and that the Dutch attitude was leading to the "collapse of the Community" ${ }^{6}$ There was however no hint of this in the final text, which stated that Europe was not solely made up of the six States bound together by the provisions of the Treaty of Rome, and should, moreover, pursue its unification in those areas not subject to Community decisions. It therefore recommended, in terms of political action, that consultations should take place "before any decision or position be taken on questions of common interest and on important foreign policy issues, with a view to reaching similar positions". This document, which does not mention the WEU, does not "for now" call for the setting up of a new institution, but advocates cooperation between the Six and candidate countries in the areas set out in the Rome Treaties. It also, however, refers to cooperation in the production and purchasing of military equipment, in specific areas of science and technology or in the matter of development aid. It was therefore a compromise between the Belgian and Dutch approaches. It was probably a little closer to Belgian views, since the Netherlands wished to propose not just a recommendation to consult before any decision, but wanted these discussions with the British to result in decisions (even without the Germans and Italians if necessary) in areas not covered by the treaties, bearing in mind that in Joseph Luns' view, technology was not one of the areas covered.

In any case, the Benelux memorandum was never taken up. This was not due solely to the attitude of Paris. Even the Commission had reservations as to the "technological cooperation" section of the memorandum. ${ }^{7}$ There was even disagreement on this point between the three Benelux ministers. Luns felt that technology did not fall under the treaties, Pierre Grégoire disagreed, and Harmel took a mid-way view. ${ }^{8}$ Nevertheless, the text is still "the first institutionalised example of practical political coordination between the Benelux countries".

\section{An attempt to sidestep French opposition to the British accession: the plan to relaunch the WEU \\ The "hidden agenda" of a small country}

The Belgian Foreign ministry had no intention of resigning itself to this failure. Belgium felt that it was important to create necessary links between the Six and Great Britain during the period until a compromise was reached. The momentum behind the drawing up and the submitting of a plan to this effect is also worthy of note. In the spring of 1968, Harmel's prestige was at a high level. The "Harmel report", which would later become a doctrine, was adopted by the Council of the

6. NAL, AMFAL, 15452.

7. NAL, AMFAL, 15439, Borschette to Luxembourg, Brussels, 02.02.1968.

8. Ibid.

9. R. de BRUIN, Les Pays-Bas et l'intégration européenne, 1957-1967, Institut d'études politiques, Paris, 1977, p.111. 
Atlantic alliance in December 1967. There were many who thought that his plan would not succeed, and would make the situation within NATO more complicated rather than simplifying things. We now know, for example, that in his personal diary, Manlio Brosio, NATO secretary general, wrote of the "Harmel dream", rather than the "Harmel exercise", that it was an "illusion", since countries would never be able to reach agreement on their political objectives. ${ }^{10}$ Maybe Harmel felt, then, that any success within the alliance could be replicated within Europe. What were the motivations of this minister, from a small country?

As we have already said, his main objective was to deal with the issue of the accession of Great Britain to the EEC. He considered the WEU the ideal place to find out whether Great Britain was ready to work together with other countries on truly European policies. But there were other possible motives. Harmel, for example, made no secret of the fact, in particular towards Michel Debré, Giuseppe Medici (French and Italian Foreign ministers, respectively), and Harold Wilson (the British Prime minister), that "Belgium's need for European unity is particular strong because only within an integrated group will Belgium be able to resolve its own problems between the language communities". ${ }^{11} \mathrm{He}$ declared before Parliament on 31 October 1962 that a new agreement on Belgian unity must be reached "to last for the next twenty or so years until European political unity has been achieved". ${ }^{12}$ Small countries, moreover, have always feared a loss of all influence within the EEC. Harmel knew that the idea of strengthening the supranational character of the Communities was still just a dream, and the Benelux countries have always felt that international links protect them from the ambitions of the larger countries. Great Britain's presence within the European institutions would help to prevent the sort of danger they feared. This is exactly what Philippe de Schoutheete, Harmel's spokesman and, jointly with Etienne Davignon (his principal private secretary), author of the Harmel plan to strengthen the WEU, welcomed, saying

"the geographical situation and history of these countries confirm that their golden rule of diplomacy must be to strike a balance between their three larger neighbours in order always to find an ally to combat any tendencies towards domination. The supranational aspect of the European agreements had been an exception to this rule in the 50s, as it brought in institutional guarantees against any attempt by one country to dominate". ${ }^{13}$

The Fouchet plan had indeed been rejected by Belgium and the Netherlands largely because it ruled out these two elements (supranationality and presence of the United Kingdom). As things then stood, the British accession could counter-balance the risk of Franco-German domination. "The Belgians wish for Great Britain to join the EEC to avoid the dangerous rivalry between France and

10. B. BAGNATO, Handling the Alliance in a Time of Change: Manlio Brosio and the Transformation of NATO, in: Nato, the Warsaw Pact, and the Rise of Détente, 1965-1972, record of the colloque de Dobbiaco, 26 to 28 December 2002, Stanford University Press, Stanford, 2004.

11. In the words of Harmel. AMFAB, 15661.

12. Annales parlementaires Chambre (APC), meeting of 31.10.1962, p.27.

13. P. de SCHOUTHEETE, La coopération politique européenne, Labor, Bruxelles, 1986, p. 18. 
Germany and to prevent these two countries dominating", states a Foreign Office report of February $1967 .{ }^{14}$ Harmel also feared, as we have already noted, "that if there is no growth, Germany will tend to take a more authoritarian and nationalistic approach and will seek other alliances which could harm Europe". ${ }^{15}$

Harmel felt, following the events of May 1968, "that we can no longer ignore the impatience and sometimes anger seething in European political circles and among the intellectual youth of Europe. The reason for the current violent reactions is a lack of guidance from leaders". ${ }^{16}$ Indeed, on 29 May 1968 the ministry's secretary general, Robert Vaes, would declare to Roderick E. Barclay, British ambassador to Brussels, that "de Gaulle's regime is over and France seems to be sinking into chaos". ${ }^{17}$

The events in Prague in August 1968 only served to strengthen the Belgian minister's views, even though nobody claimed that British membership of the Common Market would have prevented the Soviet intervention. He felt, however, that Europe "needs to make up for chaos in the East by more unity in the West". ${ }^{18}$

Finally, even though this was a secondary reason, especially for Harmel, the British could provide Belgium with valuable support as to the "war of the capitals", as is shown by a note from the European department of the Belgian ministry of Foreign affairs:

"Our fear is that the very strong negotiating position that France has managed to achieve might lead, in due course, to its demanding that the capital of the Seven countries be moved to Paris. This would be a major defeat for us, which we should try and guard against perhaps during the forthcoming discussions with the British”. ${ }^{19}$

Whatever Belgium stood to gain from the plan to relaunch the WEU, its Foreign affairs minister wished for autumn 1968 to be a time of progress "wherever this is possible" ${ }^{20}$ in the area of European integration. In Rome, on 13 September 1968, Harmel secured the support of Medici, the Italian minister of Foreign affairs. During this visit, the Belgian minister stated that it would not be too serious if France were to reject his plan. His feeling was that the plan could be developed initially without France, just as Great Britain had refused to join the EEC in 1957.

During discussions with Prime minister Wilson, Harmel would state, along the same lines, that Belgium was ready to move ahead within the WEU to promote European political unity in cooperation "with Great Britain, Germany and, if possible, France, but if necessary, without France". ${ }^{21}$

14. United Kingdom National Archives (UKNA), FO 33/14.

15. Leuven, KADOC, De Schryver Papers, 4.16.3.1.

16. AMFAB, 15661.

17. UKNA, FCO 33/7, Barclay to Stewart, Brussels, 29.05.1968.

18. Archives Générales du Royaume, Harmel Papers, (AGR, HP), Harmel to Debré, Brussels, 23.09.1968.

19. AMFAB, 15661.

20. AGR, HP, Harmel-Wilson discussions, 16.02.1967.

21. AMFAB, 15661, record of the Harmel-Wilson discussions of 18 September 1968 drawn up by the Foreign Office. 
Rome, October 1968

On 3 October 1968, Harmel revealed the main thrust of his project to the association of European journalists. He spoke firstly of the "sensation of powerlessness" felt by European leaders vis-à-vis the events in Czechoslovakia in August 1968:

"Here we have a European state, governed by a regime different from our own, admittedly, but historically and geographically closely linked with us, which is occupied by foreign troops. Other states feel under threat. But there is no voice in Europe strong enough to stand out above the noise of armies, no European power strong enough to guarantee the respect of the rule of law on our continent". ${ }^{22}$

$\mathrm{He}$ also noted that the process of European integration had been halted by the French veto to British accession, and said that since things had become "stuck in a rut", "new ideas" were needed such as "good will", and that it was vital to return quickly "to one of the two pillars" of the European integration process, "going back to its origins". He was referring to the possibilities contained in the Treaty of Brussels of 1948 and the Paris agreements of 1954, whose signatory states had declared themselves to be resolved to take the measures necessary to promote unity and encourage the gradual integration of Europe. ${ }^{23} \mathrm{He}$ wished, in this way, to promote regular consultations within the WEU on questions relating to defence, monetary issues, political issues or technology. His proposal was based on something he had observed: that while there had been progress on economic solidarity within the EEC, no headway was being made on political issues or enlargement. He therefore wished to

"move beyond the stage of occasional meetings (within the WEU) to, at least, mandatory consultation on subjects to be agreed upon, and thus to take an important step forward towards harmonising our external policies".

To this end, he referred to article 8 of the Treaty of Brussels, which allows discussion of the issues of enlargement of the WEU and ultimately of Europe. ${ }^{24}$ While wishing to awaken the "Sleeping Beauty" that was the WEU, Harmel wanted to confirm the importance he attached to the Community of Six countries and to its internal development in all areas falling under the Treaty of Rome, including those which involve the greatest amount of technological development. On this last point, as we have said, Harmel had clear differences of opinion with his Dutch colleague, who felt that technological cooperation was not one of the normal activities of the Communities. ${ }^{25}$ Yet for Harmel "this whole question of internal

22. Text of the speech in AGR, HP.

23. For Harmel, the other pillar was the Communities.

24. It states that "for the purposes of strengthening peace and security and of promoting unity and of encouraging the progressive integration of Europe and closer co-operation between Them and with other European organisations, the High Contracting Parties to the Brussels Treaty shall create a Council to consider matters concerning the execution of this Treaty and of its Protocols and their Annexes".

25. AMFAF, Europe 1966-1970, International organisations WEU, 2024, note "Harmel plans to relaunch the WEU”, 14.10.1968. 
development of the Communities, which everyone supports, must not be used to excuse the absence of or replace a common political vision of the future of Europe, voiced within the Community or elsewhere". He therefore felt that other avenues should be explored, such as foreign policy, defence (to create within NATO what would be the European pillar of the alliance), as well as technology and monetary issues ("in order to play a key role in world monetary policy"). Harmel also stressed that

"this wish to pursue unity and integration, proclaimed twenty years ago, contains no time-limit within the text. It is not restricted to certain sectors, the text does not even state which countries could be involved. It is a fundamental declaration of intent, which has borne fruit, since it was at the origins of the European institutions as we know them".

He also added that "the letter and the spirit of the treaties would be violated if, either within the Common Market or in the WEU, coalitions were to be formed against a member country, or if one or two countries were to try and dominate the others". This must surely be a reference to the Franco-German treaty and to the French refusal to agree to Great Britain's request to join.

To the Belgian Foreign affairs minister, the WEU seemed to be a better place than the EEC for welcoming new countries, until such time as the disagreements on the political objectives and on enlargement of the Common Market gave way to the opening of official, or at least unofficial, accession negotiations with candidate countries. At this stage he was in no way wishing to undermine the prerogatives of the EEC.

"The Treaty of Rome and the Communities set up by that treaty are the key and central point of current European cooperation", he would write.

"The requests for accession from Great Britain, Norway, Denmark and Ireland confirm this. It is therefore vital that the new moves being mooted should lead to one sole European integration process based on the existing Communities. The new, fragmentary initiatives must be able to fit into this design". ${ }^{26}$

He added on this point that it was not by chance that the Spaak Committee, mandated by the conference of Messina to draft the future Treaty of Rome, was originally made up of representatives of the seven member countries of the WEU. $\mathrm{He}$ also stressed that while political and defence-related issues "are clearly well outside the remit of the Communities", technology and monetary matters "do affect them in certain ways". He felt therefore, that "without creating legal difficulties and in order merely to be effective, certain types of cooperation should be organised, with the Communities, as appropriate to the areas in question". Harmel concluded by saying that it was important not to take "too narrow and legalistic a view of things" if "a Europe of European wills" were to be created, "wherever possible", when time comes "to choose between a nationalistic reflex and effective cooperation". ${ }^{27}$

26. AGR, HP, note, 13.11.1968.

27. Text of the speech in AGR, HP. 


\section{Mixed reactions: British enthusiasm, disagreement in Paris, little support elsewhere}

The Foreign Office reacted enthusiastically to Harmel's plan. Michael Stewart spoke to the association of European journalists the day after the plan was presented, and welcomed in particular the fact that Harmel was ready to move ahead without France. ${ }^{28}$ In his speech of 3 October, Harmel confirmed:

"No train would ever leave the station if it had to wait until all passengers were ready to go. The real rule to respect is to avoid people leaving once they are on board, but not to be discouraged in any project if fewer people start with you than you had hoped". 29

In Paris, however, Harmel's plan was judged unacceptable since it would give "the United Kingdom the means to control what was done by the Six" in the areas mentioned in the Belgian document. It also envisaged, moreover, systematic consultation in the area of foreign and defence policy, which implied, thought France, a minimum level of agreement on key ideas if truly European lines of action were to be developed. "But", protested the Quai d'Orsay, "how could it be that what has proved to be impossible between the Six countries would become possible when the United Kingdom were added". ${ }^{30}$ The president of the Commission, Jean Rey, was more than hesitant and declared that there should be no "dreams of a fourth community". 31

Nevertheless, in Rome, on 21 October 1968, in the presence of his WEU counterparts, the Belgian Foreign minister, who had received the support of the European movement, made an official presentation of his plan to his colleagues, and had returned to the ideas developed on 3 October. ${ }^{32}$ Harmel was unable to whip up enthusiasm for his plan. The UK delegation was the only one to really support him. The Germans were being careful not to annoy France. Even the Dutch seemed rather unenthusiastic. The French permanent representative to the Communities had claimed as early as 16 October that "the Netherlands and Luxembourg have reservations as to Harmel's proposals, which they feel to be 'rather unrealistic, not to say woolly"', ${ }^{33}$ As for Jean Rey, he would declare two days later that he understood why Harmel had taken this initiative to extend European cooperation, but that he felt that the proposals were unwise. ${ }^{34}$

The debate would also quickly become embittered on questions of procedure, even before issues of substance were addressed. Jean De Lipkowski, who Luns felt to be no more than a "smoke-screen", ${ }^{35}$ stated that, if pushed, France could agree to

\footnotetext{
28. FCO 30/462, Stewart to Crosland, 04.10.1968.

29. Full text in AGR, HP.

30. Département d'Information et presse du Ministère des Affaires étrangères, La France et la crise de l'UEO, Paris, Mars 1969, in: Europe 1966-1970, op.cit.

31. La Libre Belgique, 16.10.1968.

32. The full text can be found in AGR, HP.

33. AMFAF, Europe 1966-1970, op.cit., Boegner to Paris, 16.10.1968.

34. Ibid., Boegner to Paris, 18.10.1968, based on comments from Jean Rey.

35. GANL, Dutch Council of ministers, 01.12.1967.
} 
the group of WEU permanent representatives studying the list of subjects to be addressed under the Harmel proposal, with a view to another meeting in January. This would, however, be done as part of their normal work, and discussions would be limited to foreign policy issues. The other delegations, especially Germany, the UK and the Netherlands, insisted that a special group should be set up, made up of experts, or at least of permanent members assisted by experts.

To summarise, the Harmel plan was a complete failure. Belgium then adopted a fall-back position. Having presented his plan in Rome, Harmel would not have to deal only with the French. In London, there was great anger as to the turn events had taken and, in particular, the attitude of the Belgian minister. The Foreign Office had placed a great deal of hope in the Belgian plan. Ambassador Barclay had, only a few weeks previously, expressed his satisfaction that Harmel had been re-appointed as minister of Foreign affairs in the Eyskens cabinet which had replaced the Vanden Boeynants government in June $1968 .{ }^{36}$ Following the Rome meeting, however, the British would finally take the view that "Harmel takes too many initiatives for a small country" ${ }^{37}$ The Belgian minister would respond to this type of criticism in the Senate on 15 January, saying:

"It is not silly and pointless for a country of the size of ours to become involved in world affairs. How could we leave it up to the larger countries to bring their influence to bear? There could be no greater danger than to give in to the temptation to cut ourselves off, when we share the responsibility of building Europe with our neighbours. We hear so often that the United States or the USSR have too much influence. But who would dare to complain of this when Europe remains silent"? ${ }^{38}$

As for the British, the tone used in diplomatic reports had changed a great deal compared to the years between 1966 and September 1968. Stewart too was very disappointed. He wrote to Willy Brandt two days after the Rome meeting saying that he hoped that his German counterpart shared his disappointment as to "the meagre results of the WEU meeting in Rome". The secretary to the Foreign Office mentioned again "de Lipkowski's instructions to prevent Great Britain and the Six cooperating within the WEU". Finally he asked for support to be given to Harmel, who was to submit his plan at the January WEU meeting. ${ }^{39}$ In fact, though, Stewart was no longer counting on the Belgian minister, even though two months later he would point out to Wilson one positive consequence of the Belgian initiative. "The Harmel plan, as you said, was a useful proposal. It put the British approach into the forefront of European events for five months or so" 40

36. UKNA, FCO 33/7, Barclay to Stewart, Brussels, 17.06.1968.

37. UKNA, FCO 33/10, J.K. Drinkall to Willy (name not mentioned), 15.06.1967.

38. APS, 15.01.1969.

39. UKNA, FCO 30/533, Stewart to Brandt, London, 23.10.1968.

40. UKNA, FCO 30/535, Stewart to Wilson, London, 17.12.1968. 


\section{Back-tracking?}

It would be going too far to say that Harmel's plan was dropped straightaway. In November 1968, Sir Geoffrey Freitas, president of the Consultative assembly of the Council of Europe, wrote to Paul Struye, who, as president of the Belgian Senate chaired the Assembly's Foreign policy committee, to tell him that he felt the Council of Europe to be "the most appropriate organisation to meet most of M. Harmel's objectives, which he has explained at recent WEU meetings". ${ }^{41}$ Some, like the agency Europe, still felt however that if the institutions were fighting among themselves for the Harmel plan, it could not be completely worthless, "that it must contain something viable, must correspond to a need and have chances of success", since "people do not usually fight to claim paternity of a still-born child, as someone has described this plan". ${ }^{4}$

Moreover, during an unofficial ministerial meeting held in Brussels on 14 November 1968 between WEU member states minus France, Medici was asked to call together an expert group to meet in Rome in order to prepare a working document for the next ministerial council. The idea of a "special group", which, in Harmel's mind would lead to the setting up of a secretariat, had already been discarded. But Pietro Nenni, who replaced Medici, took up a key idea of Harmel's plan, i.e. mandatory prior consultation on a considerable number of foreign policy issues, including "the political organisation of Europe for the purposes of integration". He paraphrased the ideas put forward by Harmel in Rome, aiming to step up cooperation in the areas of foreign policy, defence, technology and monetary issues. The document even contains some of the expressions used by Harmel, copied out word for word. ${ }^{43}$ France became agitated once again and warned its EEC partners one week before the WEU ministerial meeting to be held in Luxembourg that any attempt to impose systematic consultations on France would lead it "to reconsider the nature, maybe even the principle, of its participation in Council work". ${ }^{44}$ However Harmel himself did not expect too much from this work of the so-called "Medici group", now the "Nenni group", at a time when he himself wished to "take a back seat" and "return to his role as an intermediary, trying whenever possible to guide discussions on European cooperation in directions in line with French views". ${ }^{45} \mathrm{He}$ was resolved not to isolate France and to find a compromise. Harmel was now not expecting miracles, and he was quite right, since on 14 November, Kurt-Georg Kiesinger told him that apart from the question of foreign policy cooperation, the Belgian proposals were in danger of "disrupting the Communities". ${ }^{4}$

\footnotetext{
41. The correspondence may be found in an annex to a note from the sub-directorate for Western Europe at the Quai d'Orsay, 28.11.1968. AMFAF, Europe 1966-1970, op.cit.

42. Europe, 12.12.1968. Expression attributed to Michel Debré.

43. NARA, DOS, Belgium, 969.000/1869, Rome, 15.01.1969.

44. La France et la crise de l'UEO, op.cit.

45. AMFAF, 2269, de Crouy-Chanel to Debré, 26.11.1968.

46. AMFAB, 15661, record of the meeting.
} 
On 18 December, moreover, the Germans gave the French, through their embassy in Paris, an unofficial document in which they "express disapproval of the setting up of special bodies within the WEU to deal with monetary and economic issues". The idea of the WEU Council dealing with technological cooperation "did not seem appropriate" either., In order to promote foreign policy cooperation, the Germans however welcomed the proposal for "mandatory prior consultations" in pre-determined areas, but recognised how difficult the choice of these areas would be. ${ }^{47}$ Basically, then, the German proposal would strip Harmel's plan of at least three quarters of its substance. As for the Dutch government, its ambassador in Paris confirmed that he "could generally support the essence of the Harmel plan as formulated by the Medici working group". ${ }^{48}$ But Luns, to whom de Gaulle would say just before 17 April 1969 that "the WEU is a machine used by the English" confided to Debré, on 5 December 1968, that "the Harmel Plan was a problem for his country", which wished for an understanding to be reached between France and Great Britain outside the WEU. He "would not therefore support Harmel's plan but he would listen". The Dutch minister, who also claimed to be concerned by German predominance in Europe, would thus encourage secret negotiations between France and Great Britain concerning the latter's accession to Europe. This becomes particularly interesting in the light of the importance of the Soames affair a few months later. ${ }^{49}$

Quite reassured by these various discussions, Paris decided to make a minor concession and announced to Harmel on 11 January 1969 that France was ready to participate in "a very free exchange of views in Luxembourg on ways to improve foreign policy consultation within the WEU", but rejected the three other areas (defence, technology, monetary matters). Harmel showed appreciation of the French gesture. ${ }^{50}$ Four days later, the Quai d'Orsay claimed that

"M. Harmel's initial proposals on strengthening the WEU will probably be watered down at the forthcoming ministerial meeting in Luxembourg on 6 February 1969, to become solely a study of ways to improve foreign policy consultations". ${ }^{1}$

\section{A clear link with the Soames affair?}

There was, moreover, a direct link between the plan to relaunch the WEU and the aforementioned Soames affair. Since the Belgian proposal was not viable, Christopher Soames - Winston Churchill's son-in-law and British ambassador to Paris - wondered why one should not consider the option of bilateral discussions, to bring an end to this "near-war" situation? He mentioned this possibility during conversations with Debré on 25 November 1968, and three weeks later, with

47. AMFAF, Europe 1966-1970, op.cit., directorate for Western Europe, 19.12.1968.

48. Ibid., 2476, Political directorate for Western Europe, 25.02.1969.

49. AMFAF, Secretariat general, Conversations and messages, 1968, n²8. See also M. PINE, British

Personal Diplomacy and Public Policy: the Soames Affair, in: JEIH, 2(2004), pp.59-76.

50. AMFAF, 2269, de Crouy-Chanel to Paris, Brussels, 13.01.1969.

51. AMFAF, 2024, note from the directorate for Western Europe, 15.01.1969. 
Bernard Tricot, the secretary general at the Elysée. Soames himself believed that the key thing was to reach an agreement on Britain's role in Europe, whereas Community agreements "only had value", he said, "if based on prior political agreement. If we wish to achieve accession, we must be seen to take an interest in the Harmel plan". ${ }^{2}$ Wilson sent a record of the meeting between de Gaulle and Soames to the ambassadors of the five other countries to London on 11 February. Paris therefore saw a clear direct link between the WEU crisis and the Soames affair. They suspected that London had been trying to turn France's EEC partners against her in order "to include them in the English plan to set up a system for mandatory permanent consultations outside France", and by inciting them, with this information, to go to London on 14 February, (i.e. three days after Wilson had informed them of the content of the famous meeting between de Gaulle and Soames), and "to support the English offensive within the WEU". 53

\section{A crisis looms}

Just before the Luxembourg meeting, Harmel clearly intended to adopt a fall-back position. He intended to be supremely cautious. Even in November, there had been complaints in The Hague as to the "minimalist" position of the Belgians ${ }^{54}$ As the United States ambassador wrote, Harmel had seen how little room for manoeuvre he had, since if he were to carry on putting pressure on France to allow enlargement, he risked jeopardising the stability of the existing group. ${ }^{55}$ The history of European integration had indeed shown that progress in Europe has never been achieved against the will of a big country.

The British, however, still harboured hopes of seeing the Belgian plan relaunched by the Italians, although they realised that "once again its success will depend on the French position". ${ }^{56}$ They realised that the Germans were not very keen, that Luxembourg was no more optimistic than Belgium. On 9 January 1969, Stewart instructed the British embassies in the six member states to try to move ahead without France, recalling Harmel's words: "the train must leave even if not all the passengers are ready". ${ }^{57}$ A true diplomatic offensive was launched, mainly targeting Germany, Italy and the Netherlands, especially the last two of these. Stewart would even be prepared to enter into a cooperation agreement based on the Benelux memorandum with just the Italians and the Dutch, or even with only the Dutch if all others were to turn him down. ${ }^{58}$ The Foreign Office also informed Luns that if the Luxembourg conference were to fail, there might be better results in

52. M. VAÏSSE, La grandeur. Politique étrangère du général de Gaulle, 1958-1969, Fayard, Paris, 1998, p.608.

53. La France et la crise de l'UEO, op.cit.

54. AMFANL, 999.21 WEU, 55.

55. NARA, DOS, 969000/1870, Ridgway B. Knight to secretary of State, Brussels, 12.11.1968.

56. UKNA, FCO 30/534, Hancock to Ledewidge (British embassy in Paris), London, 29.11.1968.

57. UKNA, FCO 30/534, Stewart to the embassies, London, 09.01.1969.

58. GANL, Council of ministers of the Dutch government, 01.11.1968. 
terms of political cooperation at The Hague, under the Dutch presidency, which might re-table the Benelux plan. ${ }^{59}$ No one now, quite clearly, expected anything more from Belgium. The papers written by British officials speak very harshly about the Belgian minister and his main co-worker, Etienne Davignon.

\section{A casus belli}

Contrary to French hopes, the affair would not be shelved at the WEU ministerial meeting on 6 and 7 February in Luxembourg; quite the opposite. Despite the warnings from France, Stewart, who did not want the Luxembourg meeting to finally seal the fate of the Harmel plan, announced his intention to invite the permanent representatives to London, on 14 February, to discuss the situation in the Middle East. A crisis was looming. France saw the British proposal as a casus belli. It felt that this was a way of starting a process of systematic political consultations and thus by-passing French opposition to the ideas contained in the Harmel plan. France therefore refused to participate in this meeting and felt that it could not take place without violating the rule on unanimity. The meeting was nevertheless maintained, with all countries represented except for France, "thus violating the rule of unanimity", claimed Paris. ${ }^{60}$ France then announced that it would practice an empty chair policy in the WEU until such time as the principle of unanimity was respected.

The stalemate continued. Harmel made an important move. The timing was significant. His friend Maurice Schumann had just replaced Debré, and de Gaulle had left power on 28 April 1969. On 10 June 1969 the Belgian minister submitted a memorandum to all WEU partners, to table some suggestions aimed at bringing the crisis to an end. This crisis lost its sting when the French lifted the veto on British accession. Not all problems could however be resolved so quickly. France, moreover, rejected the new Belgian text out of hand. Paris felt that the Belgian document contained contradictions, particularly when Harmel stated that it had been "normal WEU practice in the past" to impose discussion of various topics, although he acknowledged that there had been procedural problems, especially "in Luxembourg (on 6 February 1969), when there was no agenda to speak of". The Quai d'Orsay felt that the Belgian text "shows no attempt to work towards a compromise, since it repeats the main points in the Harmel plan".

\section{The "WEU sleeping beauty" can return to her slumber}

On 23 September 1969, Harmel, as future president of the WEU, came back with a new proposal, since he "would be extremely pleased if the problems within the WEU could be solved during the Belgian Presidency" ${ }^{61}$ His suggestion contained

59. AMFANL, 999.21 WEU 55, J.A. de Ranitz to Luns, The Hague, 28.01.1969.

60. AMFAF, Europe 1966-1970, op.cit., 2025, internal note, 25.06.1969.

61. Ibid., Harmel to Schumann, 26.09.1969. 
various points. WEU members should first of all re-state the importance they attached to the treaty, then declare that nobody intended to use the WEU as a court of appeal for discussions within the Communities. Ministerial meetings, as well as those of the permanent representatives, would be divided into two parts. One part would be an official meeting, with an agenda, adopted unanimously, and minutes. The other part would be a restricted session of informal nature, allowing parties to discuss subjects of their choice. Finally, the new procedures "could be contained in a set of rules of procedure, adopted unanimously, in order to avoid any further surprises". ${ }^{2}$

The French were very happy with the first and last points, even though they wished to avoid too solemn a declaration "of loyalty to the treaty". The treaty, after all, states in its preamble that contracting parties are resolved "to take the measures necessary to promote unity and to encourage the progressive integration of Europe". The French wished "to avoid any risk of interference between the work of the six countries and that of the seven". They were also going against the treaty in that they had never agreed to give the WEU arms control agency information concerning their stocks of nuclear weapons. This ran counter to article III of protocol III, which states that the level of stocks should be set by a decision of the WEU Council "taken by a majority of votes". However, Paris argued that the American stocks stored in Europe were not subject to any type of control, and that this excused France from having to follow this point in the treaty. However, the point which the French were most unhappy with was that concerning the splitting up of Council or representatives' meetings. They felt that in any case the "informal" meetings would cause problems, since it would be difficult to oppose on every occasion the conclusions of these meetings, which would moreover be institutionalised - especially if these political consultations would also take place between the permanent representatives. This part of the Belgian proposal upset the French even more as since the decision of the Six taken on 11 July 1963, the EEC Commission took part in the quarterly WEU discussions on the economic situation within Europe. This decision, taken after the failure of talks between the EEC and Great Britain, meant that the WEU no longer only dealt with essentially military topics, but also discussed political and economic issues. So the third point of the Belgian proposal would lead, in the view of the French, to the working out of new cooperation mechanisms involving seven countries. They felt then that "any reference to the permanent representatives" should be removed, and that discussions on the economic situation in Europe should be excluded from the restricted ministerial meetings. Otherwise, they felt, the procedure for restricted sessions would bypass the unanimity rule, "limiting its application to the official sessions which would then only discuss minor matters". ${ }^{63}$

To try and meet the French concerns, Harmel, just after the summit in The Hague, made a new concession in the guise of a letter sent to Schumann. $\mathrm{He}$ 
proposed that a ministerial WEU meeting should be held at the beginning of 1970 . After discussing the points on the agenda, the Council in restricted session "i.e. heads of delegation, permanent representatives and one other member per delegation" should enable the ministers

"to have a very free discussion, off the record, of any political issues of interest to them. There would be no precise agenda, but, in so far as possible, prior information would be given by the permanent representatives as to the topics which the various Ministers wished to raise". ${ }^{64}$

So no more was said about economic problems being discussed in this way. Nevertheless, a day on the economy would also be organised, where problems concerning the EEC would not be dealt with, wrote the Belgian minister. Finally he suggested that all ministerial meetings of the Council should take this format "which would encourage consultation between member States without causing new legal problems". ${ }^{65}$ Schumann considered the suggestions being "a considerable contribution towards resolving the problems currently raised by France". He nonetheless stated that "some of the points made, though, require further study by the French authorities, France will not, therefore, be present at the meeting you intend to chair in the near future". 66

On 9 January 1970, Harmel, as the then president of the WEU Council, was mandated by his colleagues to make proposals to resolve the disagreements. When Schumann met him again in Brussels, on 20 March, Harmel reassured him that both on a ministerial and a permanent representatives level, no question could be put on the agenda if one member State objected. ${ }^{67}$ The French Minister then felt that the time was ripe to prepare a declaration of the seven member States, when they met at the next session. The wording for the declaration was proposed by Harmel on 14 April 1970:

"All member States have agreed not to discuss within the WEU any technical or eco-
nomic issues relating to enlargement of the European Communities, nor any
directly-related political issues. Clearly this provision will not affect the right of
States to discuss within the WEU, in line with article 8(4) of the revised Treaty of
Brussels, problems concerning the political integration of Europe". ${ }^{8}$

In his reply Schumann wrote, "I am pleased to inform you that I can fully agree to your text". ${ }^{69}$ The crisis was over at last. France would return to WEU Councils. As the US ambassador to Brussels would say, Harmel had been able to "repair the damage". ${ }^{70}$

64. AGR, HP, Harmel to Schumann, Brussels, 04.12.1969.

65. Ibid.

66. AGR, HP, Schumann to Harmel, Brussels, 15.12.1969.

67. AMFAF, Europe 1966-1970, op.cit., 2025, Schumann to the embassies, Paris, 23 March 1970.

68. AGR, HP, Harmel to Schumann, Brussels, 14.04.1970.

69. Ibid., Schumann to Harmel, Paris, 16.04.1970.

70. NARA, DOS, Belgium, 969033/212, J.S.D. Eisenhower to DOS, 20.05.1970. 
All in all, Harmel had been forced to capitulate, and the other members had followed suit. But he could do so, since after the summit in The Hague, the "WEU sleeping beauty", which he had hoped to "awaken", would be able to return to her slumber.

\section{Conclusions}

The October 1968 plan to give the WEU new importance in political, monetary and defence-related matters, was a total failure. Its consequences were only really and fully dealt with at the summit of The Hague in December 1969. Looking back over the political career of Pierre Harmel, his initiative seems even more surprising. How could this eminently cautious man, whom some had criticised as being too keen to find a modus vivendi even if it meant sacrificing his own personal views, have given the famous speech at Rome, which was bound to annoy the French and to seem "a great blunder"? The Luxembourg compromise, which Harmel had helped to prepare - not being fully involved, but sufficiently to be aware of its importance - had shown that Europe could not move ahead against the wishes of a big country. Harmel had moreover tried later on a number of times successfully to find a compromise between "the larger countries", in areas such as monetary or political union or enlargement negotiations. He was an ally of the British, whatever they might think, and probably provided one of the strongest Western European support for Willy Brandt. He was passionate about strengthening the Benelux union, while attempting to avoid clashes with the French, by cushioning, in particular, the Dutch "offensives", although he would not be particularly successful in this. And if we remember his discussions with the Italians, showing some sympathy especially following this plan to relaunch the WEU, it is understandable that the Belgian Foreign minister should have wished to use his finely attuned ear and his inventive mind to further European integration "in all possible areas", as he said, by trying to play the "go-between" like some of his predecessors. He was thus able to see how difficult it is for a small country to get the upper hand when the larger countries do not share its interests. Clearly general de Gaulle's second veto in December 1967 had greatly irritated him; the events of May 1968 in France, then those in Prague, as well as fears of a new upsurge in German nationalism, had persuaded him that progress must be made in European integration "wherever this is possible" and with anyone willing to go ahead. The Louvain issue and the problems between the communities in Belgium had finally convinced him that it was no longer possible for the situation to remain as it was. France could no longer, he felt, object to both supranational institutions and enlargement.

The WEU crisis also brought to the surface tensions between bigger and smaller countries. Harmel explained this to Wilson on 31 January 1967. "Europe", he said, "can only evolve if two conditions are met: if it includes larger countries and if a balance can be struck between them. The smaller European States will of course agree to this equality being accompanied by greater powers within the Community for the larger countries, but only as long as these larger countries find a balance 
between themselves[...] without any of the three dominating". ${ }^{71}$ This explains the Benelux memorandum of January 1968 and the October plan to relaunch the WEU. In a note sent to his minister in February 1967, the French ambassador to Brussels stated that the role of any small country when it came to foreign policy was "to do its utmost to avoid becoming subject to a large country. For as is said in a Flemish proverb, "when the least powerful eat cherries with the most powerful, they end up with all the stones". He continues, saying that "in the light of France's current neutral foreign policy, and since the Federal Republic is on the look-out for a new foreign policy, the word in Brussels is that if these two reach an understanding, the small countries would fear a loss of all influence and subjection to the will of these two". 72

Neither is it surprising that a direct link can be drawn between this crisis and the Soames affair. The WEU crisis of 1968-1970 did place the question of British accession at the forefront of European affairs for a few months. It also showed France once again the great importance attached by its EEC partners to enlargement. In this sense, the WEU crisis perhaps made an unquantifiable contribution to convincing president Georges Pompidou that France could no longer oppose enlargement.

71. AGR, HP.

72. AMFAF, 2269, de Crouy-Chanel to Couve de Murville, 23.02.1967 
